\title{
Деятельность православных епископов по развитию просвещения в городе Хлынове (1737-1752 гг.)
}

\author{
Владимир Помелов, \\ ФГБОУ ВО «Вятский государственный университет», кафедра педагогики \\ Kirów, Rosja \\ lena_bigstar@mail.ru
}

\section{Людмила Сахарова,}

ФГБОУ ВО Кировский ГМУ Минздрава РФ, кафедра гуманитарных и социальных наук кандидат исторических наук, доцент, заведующая кафедрой гуманитарных и социальных наук

Kirów, Rosja

slg75@rambler.ru

\author{
Василий Сахаров \\ ФГБОУ ВО «Вятский государственный университет», кафедра педагогики \\ Kirów, Rosja \\ vas701@rambler.ru
}

\begin{abstract}
V. Pomelov, L. Sakharova, V. Sakharov, Activities of Orthodox bishops in the development of education in the city of Hlynov (17371752), Elpis, 20 2018: 111-117.

V. Pomelov, L. Sakharova, V. Sakharov, Działalność prawosławnych biskupów w rozwoju edukacji w mieście Chlynowie (17371752), Elpis, 20 2018: 111-117.
\end{abstract}

\begin{abstract}
Аннотация: В статье дается изложение событий, имевших место в городе Хлынове (Вятка) в 1737-1752 гг. В центре внимания - деятельность епископов по развитию просвещения. Славяно-латинская школа, основанная в 1734 г. епископом Лаврентием Горкой, получила дальнейшее развитие в этот период.
\end{abstract}

\begin{abstract}
The article gives an account of the events that took place in the town of Khlynov (Vyatka) in 1737-1752. The focus is on the activity of bishops in the development of education. The Slavic-Latin school, founded in 1734 by Bishop Lavrenty (Gorka), was further developed during this period.

Streszczenie: Artykuł opisuje wydarzenia, które miały miejsce w mieście Chłynow (Vyatka) w latach 1737-1752. Szczególną uwagę zwraca się na działalność biskupów w zakresie rozwoju edukacji.W tym okresie powstała szkoła słowiańsko-łacińska, założona w 1734 r. przez biskupa Laurencjusza Gorki.
\end{abstract}

Ключевые слова: город Хлынов, Киприан Скрипицын, Вениамин Сахновский, Варлаам Скамницкий, Антоний Илляшевич, М.Е. Финицкий, Вятская славяно-латинская школа

Keywords: the city of Khlynov, Kiprian Skripitsyn, Veniamin Sakhnovsky, Varlaam Skamnitsky, Anthony Illiashevich, M.E. Finizky, the Vyatka Slavonic-Latein school

Słowa kluczowe: miasto Chłynow, Kiprian Skripicyn, Weniamin Sachnowski, Warlaam Skamnicki, Anthony Illiaszevicz, M.E.Finicki, Wiacka szkoła słowiańsko-łacińska

Сразу после смерти первого просветителя «на Вятке», хлыновского епископа Лаврентия Горки, имевшей место 10 (21) апреля 1737 г., в городе Хдынове, главном городе Вятской провинции, последовал взрыв ненависти к его славяно-латинской школе со стороны подстрекавшихся противниками просвещения мирянами. Близкий друг и соратник Горки архимандрит Богословского монастыря, (находившегося непосредственно за городской чертой) Лаврентий Полторацкий длительное время вообще не смел показываться в Хлынове, и даже не присутствовал на панихиде по Горке.

Первый хлыновский учитель Михаил Евстафьевич Финицкий был вынужден, опасаясь репрессий, покинуть школу, и спрятался в келье Богословского монастыря вместе с его настоятелем. Пытаясь поставить в известность Святейший Синод о наступившем в Хлынове безвластии, Финицкий, выпросив у Полторацкого лошадь, отправился спустя несколько дней после смерти Л. Горки в Москву, но был схвачен в вятском 
городе Котельниче, в 100 км от Хлынова, и в колодках доставлен в Хлынов, где просидел под стражей в провинциальной канцелярии три недели.

Предоставленные самим себе ученики разбегались. Только 18 апреля 1837 г. бежало 159 учеников. М.Е. Финицкий пишет два прошения в Святейший Синод (12 апреля 1737 г. и 13 июля 1737 г.). В последнем прошении он отмечает: «По преставлению преосвященного Лаврентия студенты, оставя школьное учение, бежали и в школу не ходят, а 18 апреля, видя меня заарестована их (управителей архиерейского дома казначея Трифона и секретаря Протопопова) промыслом, и тож студенты, которые имели охоту по учению, в конец разошлися. Вси соборяне и вси причетники церковные, как градские, так и уездные, враждуют и сему школьному латинскому учению весьма неблагодарны суть, и говорят, что де сие учение не на пользу нам есть, паче же и противно церкви, понеже де мы латынь гнушаемся, а они учителя латынщики своим учением с латынами в сообщение нас хотят привести, о чем соборяне и прочие попы градские намерены просить вашего святейшества о отмене онаго учения» [5, с. 319-320]. Он писал также, что ему, Финицкому, «при школах быть весьма трудно» и что его может заменить Богомедлевский, а сам он желает удалиться из Хлынова [5, с. 317].

Большинство хлыновского духовенства полагало, что школа - затея «поляка-архиерея» епископа Лаврентия Горки со смертью «затейщика» «покончится». И действительно, первые два месяца после смерти Горки были временем ее полной дезорганизации. Однако уже в середине июня 1737 г. был получен указ Святейшего синода с требованием «содержать школы как было при жизни преосвященного Лаврентия во всем неотменно». Местные противники школы несколько утихли, а Духовный Приказ начал принимать меры к возвращению беглецов-учеников в школу.

Положение, однако, осложнялось тем, что назначенный вместо Горки епископом Киприан Скрипицын управлял епархией, так сказать, заочно. За два года, пока он числился в этой должности, Киприан так ни разу и не удосужился побывать в Хлынове, и управлял епархией посредством издания указов и пересылки указов из Санкт-Петербурга. Эти указы нередко игнорировались, поэтому хлыновские духовные власти смело писали епископу Киприану, что «содержать оных школ никак не возможно» [7, с. 260]. При таком положении дел, когда количество бежавших из школы доходило даже по ведомости до 310 человек, всего во всех семи классах оставалось 120 учеников [3, с. 278], а фактически, разумеется, еще меньше. В условиях, когда ученики одну неделю занимались, а две недели находились в бегах, учение не могло идти «правильно», а успехи быть значительными.

Тяжелым в моральном и материальном отношениях было и положение работавших в ней учителей, а в особенности «зсылочного», работавшего среди враждебного по отношению к «латынщикам» духовенства, учителя-монаха Иоакима Богомедлевского, который, как стало известно местным жителям, «нарочно» ездил учиться за границу в латинские еретические школы. За все время работы в школе он получил 35 копеек, да и те не были ему выданы; в счет их на Рождество 1836 г. на 32 коп. для него были куплены 16 аршин холста и 3 коп. были уплачены за шитье [10, с. 166]. Из этого холста ему была пошита хламида - плащ с колпаком, в котором он и ходил постоянно; никакой другой одежды он не имел вообще.

Питался И. Богомедлевский в архиерейском доме вместе с другими монахами. Питанье было крайне скудным. М. Финицкий писал в донесениях в Святейший Синод в июле 1737г.: «Иеромонах Трифон, управитель архиерейского дома, мне с прочими учителями пищу прекратили, а когда ему, Трифону, начну напоминать о пище, то часто бывает, что упившися палкою на мене грозит, безчестными и поносительными укоряюще словами поносит» $[5$, с. 321$]$.

Иеромонах Иоаким Богомедлевский (около 1680 - после 1738) был очень примечательной личностью, поэтому считаем нужным представить те не5многочисленные факты его биографии, которые удалось установить. Он был сыном священником Киевской епархии. В течение 12 лет он учился в школах Киево-Братского монастыря. Префект Стефан Яворский направил его в Польшу, где он продолжил обучение во Львове, Люблине, Кракове, Варшаве, Калише. Около года Богомедлевский провел в Познани, Данциге, Кенигсберге, Вильно. Вернувшись из-за границы, он ищет «промоции» у С. Яворского, в ту пору митрополита Рязанского. Затем Богомедлевский живет в Москве и Санкт-Петербурге, ведет монашескую жизнь. У него происходит ссора (не ранее 1722 г.) с сотником знаменитого гетмана Скоропадского по фамилии Батуринский-Стожок. Последний обвинял Богомедлевского в «брани и бесчестии», а Богомедлевский, в свою очередь, жаловался на оскорбления, нанесенные ему в гетманской войсковой канцелярии.

Дело тянулось очень долго и зашло слишком далеко. В мае 1728 г. оба спорщика давали показания в Синодальной канцелярии в Москве. Затем дело было передано на рассмотрение епископу Киевскому Варлааму, а тот передал его на рассмотрение не кому-нибудь, а самому... Батуринскому-Стожку. Спустя некоторое время дело пропало, в чем Стожок не замедлил обвинить... Богомедлевского. И хотя абсурдность навета была очевидна, последний уже не надеялся на благоприятный для себя исход, и поэтому сбежал из-под стражи в Москву, самим фактом побега как бы признав свою вину. 15 июля 1731 г. его поймали и отправили в ссылку. В итоге, 9 января 1732 г. «ученый чернец» прибыл под конвоем в Хлынов, а уже на другой день в сопровождении служителя Духовного приказа Кондратия Шеломова был отправлен в самый отдаленный монастырь Вятской и Великопермской епархии - Чердынский, где содержался «в оковах неисходно за бродяжество»; по выражению вятского историка А.С. 
Верещагина, «упечатан в Чердынское заточение», положив, тем самым, начало вятской ссылки для самых передовых и образованных граждан России. В указе преосвященного епископа Чердынскому игумену Никите было предписано «бродягу Иоакима Богомедлевского держать в монастыре вовсе скована и никуды неисходна и ни до какова священнослужения его не допускать» [5, с. 302].

Лаврентий Горка хорошо знал Иоакима Богомедлевского как по одновременному с ним обучению в Киеве, так и по служению в киевских монастырях. В 1734 г. «сиделец» обратился к новому вятскому епископу Лаврентию Горке с просьбой перевести его из отдаленной Чердыни, где он находился по прежнему под присмотром игумена Никиты, дававшего «большую волю своим рукам», в какой-нибудь из ближайших к Хлынову монастырей, но ответа от него так и не получил. Узнав об открытии хлыновской славяно-латинской школы, он обратился к архимандриту Богословского монастыря Лаврентию Полторацкому, также причастному к «киевской науке» с просьбой о месте в школе. Однако Л. Горка не решился нарушать приказ Священного Синода от 10 декабря 1731 г. о его заточении. К тому же, у него были тогда подобраны два учителя на первое время.

И только летом 1736 г., перед открытием классов «пиитики да реторики» Лаврентий Горка вспомнил о «чернеце», некогда преподававшем риторику в Москве и Ростове. К тому же, экономный Горка сообразил, что денежное содержание еще одного киевского «профессора» встало бы ему дороже, нежели привлечение опального монаха, готового работать за одно пропитание. И Горка решается «достать» Иоакима Богомедлевского. Он шлет 13 августа 1736 г. указ игумену Никите: «Из железа ево расковать и привезти тебе из монастыря на Вятку к ево преосвященству на срок сего 1736 года сентября на 14 число» [5, с. 316]. «Бродяга-чернец» прослужил в школе до августа 1738 г., и его по праву можно считать третьим по счету вятским учителем, после Финицкого и Лещинского.

Иоаким Богомедлевский бежал из Хлынова, несмотря на свое «измождение», в конце августа 1738 г., а уже 30 августа поступила в Провинциальную канцелярию промемория Духовного приказа о «бежавшем иеромонахе И. Богомедлевском» с просьбой «о сыску оного». Однако ученый монах исчез бесследно, и его дальнейшая судьба осталась навсегда неизвестна.

Следом за ним навсегда покинул Хлынов и другой учитель, - Василий Лещинский, отпросившийся из Хлынова в Москву под предлогом якобы поискать для школы третьего учителя, на место бежавшего Иоакима Богомедлевского. На поиски Лещинского был отправлен в Москву архиерейский стряпчий, но ему не удалось напасть на след исчезнувшего учителя.

Если уж стремились бежать из школы «магистры», «одержимые крайнею убожества скудостью в препитании», то чего можно было ожидать от школьников, набранных почти исключительно силой, которые смо- трели на «латинскую грамоту» как на мучение?! И они бежали, «и не было на них теперь грозы», жаловался в своем доношении Финицкий.

Для того, чтобы исполнить приказ Святейшего Синода о том, чтобы школу «держать неотменно», необходимо было, прежде всего, возвратить «из бегов» всех школьников. Духовный приказ сделал распоряжение об их сыске по «заказам», но вернуть удалось немногих, поскольку укрывателями были влиятельные лица духовного звания. А потому Духовный приказ не посмел ничего сделать с ними.

В 1739 г. Святейший Синод приказал вновь назначенному 18 мая епископом в Вятскую и Слободскую епархию бывшему Коломенскому епископу Вениамину Сахновскому поспешить с выездом на Вятку, ибо дела «на Вятке» шли все хуже. 28 сентября епископ прибыл в г. Хлынов. В. Сахновский был уроженцем сербского города Косово. В молодости он переселился в Россию. В Воронеже постригся в монахи, служил иеромонахом во флоте, был архимандритом Псковско-Печерского монастыря. С 1731 г. - епископ Коломенский.

Прежде всего, в Хлынове новый епископ обратил внимание на расстроенное состояние школы, и поэтому решил возвратить беглецов-учащихся. «В страх другим» он отправил «за упорное укрывательство сына от школьного учения» кафедрального протопопа Артемона в менее значимый Богословский монастырь. Вслед за этим во все заказы были направлены строжайшие указы с тем, чтобы «закащики, всех учеников собрав в одно место, каждый своего заказу, привезли с собою в Хлынов в назначенные сроки; а ежели они, закащики, всех на указанные сроки не представят, то лишены будут чинов своих и сверх того взято будет с них штрафу по три рубли, не приемля никаких отговорок» [1, с. 64]. Это распоряжение принесло желаемые последствия: «закащики» «бились из всех сил о сыске беглецов», и стали целыми группами привозить их в Хлынов. Но, несмотря на все свое усердие, они были не в состоянии полностью выполнить епископский указ, и не раз вынуждены были доносить «о жестоком упрямстве и нестерпимом грубиянстве» подчиненного им духовенства, привыкшего к полной безнаказанности за время служения «прежде отсутствовавшего» епископа Киприана.

Эти жалобы вынудили Вениамина решиться на «нещадное наказание телесное». Так, 6 июня 1740 г. по повелению епископа были собраны все священники, дьяконы и церковники г. Хлынова, и в их присутствии был «примерно» наказан священник села Медянского Евфимий Овчинников за его «понаровку и укрывательство беглого своего сына-школьника» [1. С. 64].

Подобные же меры, кстати, не считавшиеся в то время жестокими, были приняты и в отношении к школьникам с целью предостережения их от «утечек» из школы. Вскоре по приезду Вениамина на Вятку были подвергнуты «нещадному наказанию по школьной регуле» все те школьники, которые были «сысканы из бегов», и на «непослушанство» которых еще до 
приезда Вениамина жаловались учителя в Духовный приказ.

После столь действенных мер побеги стали редкостью. Начиная с 1740 года, попы стали не только спешить «сбывать с рук» поскорее являвшихся к ним беглецов-школьников, но и сами нередко пускались в погоню за «утеклецами», вязали их, в случае необходимости заковывали в колодки, и «за караулом» везли в Духовный приказ. Неудивительно, что к концу 1740 года в школе насчитывалось уже до 450 учащихся.

Епископ Вениамин не ограничивался, однако, одними строгими мерами к прекращению «утечек» и укрывательств. Главный упор он делал на материальное поддержание школы. Он неукоснительно требовал «двадцатой доли» от монастырей, и, по возможности, деньгами, которые были ему необходимы для выплаты зарплаты учителям. Учителям «пиитики и реторики» полагалось 72 рубля в год, учителю грамматики и синтаксимы - 40 рубля. Это было значительное для того времени жалованье.

В этом отношении характерно «Великому господину преосвященному Вениамину прошение учителя Федора Порошина от 8 февраля 1740г.»: «Сего 1740 года генваря 7 дня определен я учителем школы инфимы по указу вашим преосвященством, которые до самых вакаций обучал, а за оказанные труды никакого определенного жалованья не имею, скудостью же крайнего божества одержим есмь. Тож ради вашего преосвященства всепокорнейше прошу да благоволит ваше преосвященство приказать то либо определить за прошедшие месяцы чему достоин явью...» На этом прошении епископом Вениамином наложена резолюция: «Выдать 6 рублей. Заслуживает жалованья с января по июль» $[8$, л. 6].

Нужны были средства и на приобретение книг, питанье «убогих», то есть бедных школьников, живших при школе. Немало затрат требовал ремонт школьных изб, у которых валились печи, протекала крыша, кое где отсутствовали ставни.

Епископ Вениамин часто посещал школу, отмечал прилежных учеников, приказывал учителям «не опускать без наказания» никаких уклонений от «школьных регул». В 1739 г. он приказал открыть класс «пиитики», в 1740 г. - класс «реторики», назначив «профессором» обоих Михаила Финицкого, а преподавание в классах грамматики и синтаксимы передал от Финицкого Т. Григоровскому, которого для этой цели привез с собой из Коломенской епархии.

В 1742 г. епископ Вениамин был переведен в Воронежскую епархию. Для того, чтобы после его отъезда не повторилось то же безвластье, и школа «не упала», как это имело место сразу после смерти Лаврентия Горки, М. Финицкий, оправившийся при епископе Вениамине от «скудного во всем и горестного жития», убедил преосвященного освободить школу от опеки Духовного приказа, и учредить для нее независимое управление в виде особой «конторы». 17 января 1742 г. такая контора была учреждена.
Ей было поручено в отсутствие епископа наблюдать за исправным и своевременным «представлением» в школу священнических детей, за своевременной поставкой монастырского сбора, за успехами и поведением школьников, за всей учебной и хозяйственной деятельностью школы.

Членами конторы - этого первого на Вятской земле учреждения по организации школьного дела - были судья Духовного приказа иеромонах Иоасаф Потемкин, казначей архиерейского дома игумен Иоанн и М.Е. Финицкий. Поскольку первые двое делами школы занимались мало, фактически ею заведовал Финицкий. Иногда между членами конторы возникали разногласия, которые, обычно, разрешались к ободному удовлетворению.

Например, 21 января 1742 г. сын дьячка Белтюкова, прошедший курс обучения лишь в славянской школе, просил у конторы разрешения на женитьбу, «дабы после сочетания проситься в церковный причт». Финицкий решил определить его вместо этого в «верхнюю» школу. Но «комиссар» конторы отец И. Потемкин счел это решение чересчур суровым и предложил следующее решение: «Просителю Белтюкову законным браком сочетаться позволить, понеже он находится уже в совершеннолетних летах; ежели ж ему, Белтюкову, по желанию его, законным браком сочетаться не позволить, то паче чаяния не случилось бы греха; а чтоб от школьного учения не отлучался, взять с него, Белтюкова, обязательство и расписку (о продолжении обучения).

М.Е. Финицкий согласился с таким предложением. Епископ Вениамин повелел все указы и ведомости со времени его прибытия на Вятку, имеющие отношение к деятельности школы, по описи и под расписку сдавать в контору.

В январе 1742 г. Вениамин отправился в Москву для участия в коронации императрицы Елизаветы Петровны и, находясь в столице, видимо, «испросил промоции», ибо вскоре был переведен обратно в Воронежскую епархию. О нем осталась на Вятке добрая память как о просветителе иноверцев, любителе духовного просвещения.

Историк А.С. Верещагин высоко оценивал деятельность епископа Вениамина Сахновского в Хлынове. Его двухлетнее пребывание в Хлынове он сравнивает по своей значимости даже с периодом работы здесь Л. Горки. Не случайно и М.Е. Финицкий в своих «силлабах» также сравнивает Сахновского с Горкой:

«Угасе добротою лампада горяща ${ }^{1}$;

Втора возжеся, равные светити могуща²

Упаде веры Божией стали непоколебимый;

Днесь же ина утвердил Бог везде хвалимый. Прейде добрый пастырь, ах, над камень гробный; Взыде по нем на престол ин ему подобный.

Се Лаврентий епископ своя замте очи,

Но днесь на престол его Вениамин вскочи.

Имеется в виду смерть Л. Горки - Прим.авт.

2 Имеется в виду приезд в Хлынов епископа Вениамина - Прим.авт. 
По умершем Лаврентии, предобром пастыре,

Полно все слез и вопля во всем Вяцком мире;

Вениамин же прииде слезы утолити,

Хотяще же гладные овцы оживити» [1, с. 67-68].

Вятский историк А.В. Эммаусский считал, что крутые меры Сахновского привели лишь к искусственному подъему школы, под которым не было общественной поддержки и соответствующей материальной базы [11, с. 217].

Поэтому на долю следующего вятского епископа Варлаама Скамницкого, служившего на Вятке с 27 февраля 1743 г. по январь 1745 г., выпала задача решать вопрос о благоустройстве школы. «Определенная на содержание студентов изба, - указывалось в официальном донесении епископу в сентябре 1744 г., - как крышкою, так и углами обветшала, и к житию в ней негодна; понеже и самого приходу крыльце и двери обвалилися, к тому ж оконницы, полы, потолки, печи и самые переклады являются гнилы, и впредь уже стояти отнюдь не возможны, и к починке негодны. Да при оном же архиерейском доме три особливыя школы також, за дряхлостью печей, нагревать невозможны, а во время дождевно всюду каплет, наипаче когда снег тает» [4, с. 587].

Столь плачевное состояние школы вынудило епископа Варлаама искать другое помещение, и в октябре 1744 г. школа была устроена в кельях Успенского Трифонова монастыря, то есть на территории главного храма Вятской земли.

Бедственному состоянию помещения школы соответствовало и незавидное материальное содержание школьников. «Свечей во оной школе не малыя части не обретается, а пища обретающихся во оной студентов точию в едныя молосныя дни, а в постныя дни и праздничныя, не токмо в простыя, кроме хлеба, ни малыя части не имеется; а с сего сентября (1744 г.) не только пищи, но и квасу не выдается» [4, с. 587]. Переселение школы в кельи монастыря несколько улучшило быт, проживавших в ней учащихся. Впрочем, на школьном кошту находились самые «недостаточные» школяры, главным образом, сироты. Остальные дети а именно иногородние, как и прежде, снимали угол в городе, и питались за пределами школы.

Епископ Варлаам пытался, насколько это было возможно, заботиться и об улучшении содержания, находившихся на казенном содержании юношей. В частности, он издал такое распоряжение: «В пищу оным студентам от того Успенского монастыря, из подлежащей двадцатой доли всякого хлеба производить печеным, к тому ж квас, толокно, капусту и для варения щей крупу, а в постные праздничные дни горох и на кашу конопляное семя; во время мясоестьев на воскресные и праздничные дни у купцов брать говяжьи мяса, по полутора пуда на каждый праздничный день, и целовальнику пищу оным студентам приуготовлять в настоящее время» [2, С. 200].

Все это требовало немалых средств, и епископ Варлаам принял новые, еще более строгие меры к «утеклецам». Руководствуясь указом Святейшего Синода от 1744 г., он стал налагать на укрывателей детей от школы за каждый месяц просрочки штраф: на протопопов - 2 р., на попов - 1 р.50 к., на дьяконов - 1 р., на дьячков и пономарей - по 50 к. При этом он требовал уплаты этого штрафа «без малейшего опущения».

Через духовный приказ (с 1744 г. - духовная консистория) он слал предписания церковнослужителям епархии, которыми подтверждает «наикрепчайше», чтобы впредь те из них, чьи дети не прошли обучение в славяно-латинской школе или не представили их на «смотры» в школу на предмет их обучения, впредь не утруждали себя подачей прошений на занятие церковных должностей под грозой «не малого штрафа» $[9$, с. 49].

Тем не менее, одним из главных препятствий, которое сильно уменьшало просветительские возможности церкви, продолжало оставаться отсутствие денежных средств на содержание учащихся и выплату жалованья учителям. Несмотря ни на что, «двадцатая доля» доставлялась в архиерейский дом из монастырей и архиерейских вотчин нерегулярно, и это в значительной степени объяснялось сильными крестьянскими волнениями; крестьяне отказывались возделывать церковные земли, уклонялись от уплаты оброка.

По мере падения доходов церкви, оставалась без средств и хлыновская школа. Для того, чтобы священнические места были заняты достойными людьми, епископ предложил проводить выборы из двух-трех претендентов. Финицкому Варлаам предложил при обучении «всякими способами и упражнениями усматривать каждого устроумия, и кто же из оных весьма тупи непонятен, и не показует ли кто из себя, удаляяся чтения, притворной тупости, и о таковых через полугодное время подавать Его Преосвященству во всякой справедливости рапорты» [9, 49].

После долгих колебаний покинул школу ее первый учитель и первый руководитель, Первый Учитель на Вятской Земле Михаил Евстафьевич Финицкий. Первое «доношение» по этому поводу на имя преосвященного Варлаама он пишет 29 августа 1743 г. В нем он указывает, что «от многовременного и неусыпного в преподаянии наук труда весьма ослабел» и просит отставки. Варлаам делает на «доношении» помету для отца И. Потемкина следующего содержания: «Справиться, имеется ли такой человек у нас, который бы на место сего просителя риторическое учение преподать мог, и нам предложить».

Далее следует запрос Финицкому из Духовного приказа с тем же вопросом. Финицкий отвечает, что есть студенты, такие как Акинфей Черепанов и Михайло Шашков, которые «во учении не худы и в школьных делах на вопросы освещают и учатся не худо, а реторическое учение преподавать могут ли, в том я мнением своим не утверждаюсь, понеже инное есть учитися, а инное учити», - честно признается Финицкий. В ответ следует резюме Варлаама: «Пока приищется на его место другой учитель, удержать на время» [6, с. 97]. 
1 января 1745 г., перед самым отъездом Варлаама из Хлынова, Финицкий подает новое прошение и на сей раз получает положительный ответ. К тому времени Финицкий фактически уже не работал в школе. На его место был приглашен выпускник Казанской духовной академии Петр Глемаровский, который вступил в должность 18 октября 1744 г. Что касается Финицкого, в дальнейшем он был управляющим (воеводой) в Орлове и Чердыни. В 1773 г. служил в Хлынове в провинциальной канцелярии. А епископ Варлаам выехал из Хлынова на служение в Великий Устюг, где и скончался в 1761 г.

Следующим на Вятке епископом был Антоний Илляшевич, поляк, родом из Виленского воеводства, ранее служивший в сане архимандрита Московского Новоспасского монастыря.

В Хлынов он приехал 29 апреля 1748 г., здесь же и скончался 16 ноября 1755 г. За трехлетнее отсутствие в Хлынове епископа школа постепенно «падала» и приходила во все большее расстройство. Духовная консистория и ее главный в тот период член - протоиерей Троицкий Никон не были к ней расположены и не раз получали из столицы, видимо в ответ на жалобы учителей и учащихся, замечания о том, что в Хлынове» о пользе школы нимало не стараются» [2, c. 201].

Епископ Антоний обнаружил школу в полном запустении, без сяких средств к существованию. Вместо 400 с лишним учеников, что учились при Вениамине и Варлааме, оставалось менее половины, да и тех содержать было не на что. Помимо Успенского Трифонова монастыря, который «довольствовал» школьников печеным хлебом и квасом, все остальные монастыри доставляли за «двадцатую долю» не более ста рублей, которых недоставало даже на выплату жалованья учителям. С такими средствами, сокрушался Антоний, «не токмо на исправление нужно-потребного, но и на пропитание было недостаточество; и ученики, и за толиким оных числом, не токмо нижних школ, но и реторические студенты питались токмо единым хлебом, а харчевных припасов не точию по вся дни, но и на праздничные ничего не получали, и за тем как в препитании, так и в школьных потребах крайнюю несли нужду» [2, с. 202].

Антоний был образованным человеком, и стремился «восстановить пришедшее до него в упадок учение». Дело осложнялось тем, что с уходом Финицкого, «выпущенного в светское звание», его преемники, уступавшие ему в знаниях и твердости характера, сильно запустили школу. Антоний назначил старшим учителем ученика Финицкого Алексея Свирепова, открыл риторический класс, из которого со временем стали выходить сочинители предиков и проповедники. Епископ Антоний так ценил в Свирепове сочинителя проповедей, что приказал его, хотя «оный и малогласен», оставить при Свято-Троицком и Николаевском соборе за протодьякона, «дабы смотря на то другие при семинарии вятской студенты большую по обучению охоту и по изучению против неученых в производствии к лучшим местам надежду имели» [9, с. 59].

В то же время, следуя духу и букве «Духовного регламента», где указано, «яко не подобает академии хвалитися тем, что много учеников имеет», он приказал оставить в школе только «остроумных и надежных», а излишних «непонятных», а также из «нижних школ великорослых», совсем «от школы уволить», взяв с них при этом «за обстоящую нужду, смотря по состоянию, кто что понесть может, денежные штрафы» [2, с. 202].

Оставив в школе не более 95 учеников, Антоний сделал все необходимое для улучшения их материального содержания. Завел строгую отчетность по архиерейскому дому, следил за исправным внесением штрафов и «двадцатой доли», или денег вместо нее. Он распорядился «с произведенных и впредь производимых попов, дьяконов, также дьячков и пономарей, как в латинской школе в науках не были, на содержание студентов каждый год брать с священника по рублю, с дьякона по пятьдесят копеек, с пономаря и дьячка по 25 копеек» [2, с. 203].

Действуя решительно, придерживаясь строгой экономии, епископ Антоний добился того, что учащиеся, получая хлеб, квас и толокно по-прежнему из Успенского Трифонова монастыря, могли уже питаться в «молосныя дни» ветчиной, в праздничные - свежим мясом, гречневой кашей с маслом, в постные же дни - горохом и капустой, а «когда недорога была по продаже по праздникам и рыбой». Самые бедные из школьников «были снабдеваемы и одеждою, и прочим, кому что оказывалось особливо нужднопотребным» [2. C. 203].

В 1751 г. Антоний изыскал возможность вывести школьников из темных келий монастыря и к лету следующего года успел построить совершенно новое здание; оставалось сделать лишь некоторые внутренние работы. Таким образом епископ Антоний Илляшевич стремился к улучшению положения школы и школьников, «дабы они большую охоту имели ко учению. Он посещал духовную консисторию каждую среду и пятницу, часто заходил и в школу. Всегда сам «свидетельствовал», то сеть проводил отбор, представляемых в школу священнических детей свыше 7 лет на предмет учения. «Острых» направлял в школу, а «тупых» «увольнял от ученья, дабы напрасной надежды на производствие во священнический чин не имели» [2. С. 204]. В школе он бывал ласков и доступен, выслушивал все жалобы и «в поощрение ко учению» удовлетворял желаниям школьников, если находил это возможным.

Помимо Свирепова, он высоко ценил учителя Ушакова «за достойное их славянско-латинского диалекта учение». Если не было возможности поднять жалованье, то, по крайней мере, он всегда отдавал этим учителям предпочтение перед их малообразованными коллегами. Тех же, кто не нравился ему своей «веселой, небережливой жизнью», как, например, Радикорский, 
несмотря на все их дарования и познания, Антоний удалял из школы.

В июле 1752 г. страшный пожар обрушился на Хлынов. В огне сгорела значительная часть построек Успенского Трифонова собора, весь архиерейский дом, духовная консистория, многие церкви и дома жителей. Погибла и только что построенная школа, в которой так и не довелось поучиться хлыновским школярам. По причине наступившего бедствия стало не до учебы. С чувством глубокой горечи епископ Антоний распускает всех школьников по домам, и учение прерывается на целых шесть лет. Так завершилась история первого на Вятской земле учебного заведения - славяно-латинской школы.

\section{Литература}

Верещагин А.С. История Вятской духовной семинарии // Вятские Епархиальные Ведомости. - 1868, №4. - С. 64-72 .

Верещагин А.С. История Вятской духовной семинарии // Вятские Епархиальные ведомости. - 1868, №12. С. 197-204.

Верещагин А.С. История Вятской духовной семинарии // Вятские Епархиальные Ведомости. - 1884, №12. C. 268-280.

Верещагин А.С. Краткий очерк истории Вятской духовной семинарии // Столетие Вятской губернии: В 2 т. Вятка, 1870. T.2. - С. 581-612.

Верещагин А.С. Ученый южнорусс на Вятке в XVIII в. // Памятная книжка и календарь Вятской губернии на 1895 г. Отдел IV. - Вятка, 1894. - С. 302-321.
Два прошения М.Е. Финицкого преосвященному Варлааму Скамниикому. 1743 и 1745 г2. // Труды Вятской ученой архивной комиссии. Вып. IV. - Вятка, 1905. - С. 95-97.

Доношение преосвященному Киприану 13 марта 1739 г. // Вятские Епархиальные Ведомости. - 1884, №11. С. 260 .

Малюгин П.К. Выписки по истории школь Вятского края XVIII в. Рукопись - 40 л.

Никитников Г.А. Иерархия Вятской епархии. - Вятка, 1863. $-214 \mathrm{c}$.

Расходная книга семинарских денег на 1736г. в архив консистории // Вятские епархиальные ведомости. - 1884, №8. - С. 166.

Эммаусский А.В. Исторический очерк Вятского края XVIIXVIII вв. Киров, 1956. -260 с.

Rozmiar artykułu: 0,7 arkusza wydawniczego 


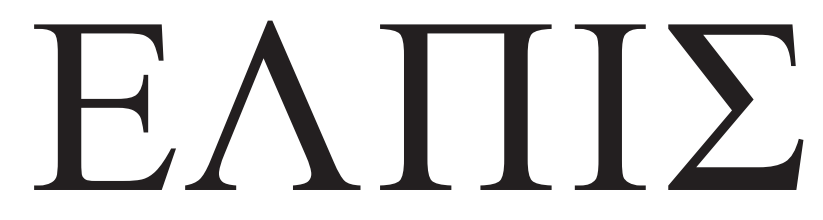

CZASOPISMO TEOLOGICZNE KATEDRY TEOLOGII PRAWOSŁAWNEJ UNIWERSYTETU W BIAŁYMSTOKU

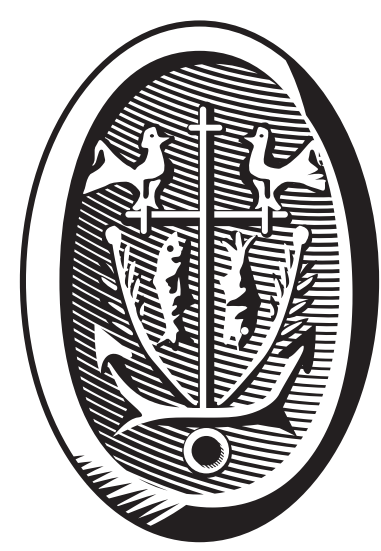

ADRES REDAKCJI

ul. Ludwika Zamenhofa 15, 15-435 Białystok, Polska tel. 85 745-77-80, e-mail: elpis@uwb.edu.pl www.elpis.uwb.edu.pl 